NBER WORKING PAPER SERIES

\title{
IMMIGRATION, INTERNATIONAL COLLABORATION, AND INNOVATION: SCIENCE AND TECHNOLOGY POLICY IN THE GLOBAL ECONOMY
}

\author{
Richard B. Freeman \\ Working Paper 20521 \\ http://www.nber.org/papers/w20521 \\ NATIONAL BUREAU OF ECONOMIC RESEARCH \\ 1050 Massachusetts Avenue \\ Cambridge, MA 02138 \\ September 2014
}

We thank The Alfred P. Sloan Foundation for support of the NBER Science and Engineering Workforce Project The views expressed herein are those of the author and do not necessarily reflect the views of the National Bureau of Economic Research.

NBER working papers are circulated for discussion and comment purposes. They have not been peerreviewed or been subject to the review by the NBER Board of Directors that accompanies official NBER publications.

(C) 2014 by Richard B. Freeman. All rights reserved. Short sections of text, not to exceed two paragraphs, may be quoted without explicit permission provided that full credit, including $(\mathbb{C}$ notice, is given to the source. 
Immigration, International Collaboration, and Innovation: Science and Technology Policy in the Global Economy

Richard B. Freeman

NBER Working Paper No. 20521

September 2014

JEL No. F22,I25,O15,O33

\begin{abstract}
Globalization of scientific and technological knowledge has reduced the US share of world scientific activity; increased the foreign-born proportion of scientists and engineers in US universities and in the US labor market; and led to greater US scientific collaborations with other countries. China's massive investments in university education and R\&D has in particular made it a special partner for the US in scientific work. These developments have substantial implications for US science and technology policy. This paper discusses several policies that U.S. policy makers might consider in responding to the changing global world of science and technology. These include aligning immigration policies more closely to the influx of international students; granting fellowships to students working on turning scientific and technological advances into commercial innovations; and requiring firms with R\&D tax credits or other government R\&D funding to develop "impact plans" to use their new knowledge to produce innovative products or processes.
\end{abstract}

Richard B. Freeman

NBER

1050 Massachusetts Avenue

Cambridge, MA 02138

freeman@nber.org 
Globalization of knowledge, knowledge creation, and innovation have widened the framework for assessing the economic effects of science and technology (S\&T) policies. As an advanced country at the frontier of knowledge, the US relies on investments in science and technology to improve economic performance and maintain comparative advantage in the high tech industries that employ highly educated workers. Expansion of tertiary education, increases in research and development spending, and the manufacturing and assembly of high tech products in low income countries as well as in other advanced countries challenges the US position at the knowledge frontier ${ }^{1}$. This makes S\&T policies more important in determining economic outcomes than in earlier post World War II decades when the US naturally dominated the production and application of knowledge to the economy.

This paper analyzes the globalization of science and engineering and knowledge production in the $21^{\text {st }}$ century and its implications for US science and technology policies.

Section I documents the spread of advanced knowledge and knowledge creation around the world in terms of its impact on the US share of the world's science and engineering activity. It stresses that the rapid catch-up in knowledge creating activities and production in low wage developing countries, most notably China, constitutes a major challenge for the US. The catch-up undermines the “North-South” model of trade that posited that advanced countries inevitably have comparative advantage in the production of high value added innovations. ${ }^{2}$

Section II shows that the catchup has "globalized” science and engineering within the US by increasing the foreign-born share of science and engineering graduate students and post-docs in US universities and the foreign-born share of the US's science and engineering work force, and by spurring

1 It also benefits the US economy. Products and services produced at lower prices in low wage countries reduce the costs of consumption in the US. Technological advances beyond or complementary to those in the US can improve US productivity. Expansion of university education and R\&D overseas creates jobs for US citizens and augments the supply of high-level immigrants to the US.

2 Krugman 1979 has the clearest statement of this model. Baumol and Gomory (2000) make the case that loss of comparative advantage in particular high valued or high-tech industries can reduce the well-being of one of the countries. Ruffin and Jones 2007 offer additional insights and a more sanguine view. 
international collaborations in knowledge production and innovation, thereby speeding knowledge creation and the spread of new knowledge worldwide.

Section III examines possible changes in US policies regarding international students, postdoctoral workers and S\&E immigrants and regarding the link between technology-based innovations and production. It argues that globalization of knowledge makes S\&T policies the "industrial policy" of the $21^{\text {st }}$ century, with implications for economic performance broadly. To maximize the benefits of the globalization of knowledge requires the US to balance investments that expand the stock of global knowledge and policies that localize a share of the gains in the domestic economy.

\section{Globalization of S\&E Activity Across Countries}

Not so long ago the US was the colossus in producing new science and technology and developing science and technology-based innovations. In 1970, with just 5-6\% of the world's population, the US had 29\% of university enrollments; over half of science and engineering PhDs; performed $40 \%$ of world R\&D; wrote $32 \%$ of all scientific papers and $57 \%$ of the most highly cited papers. $^{3}$ The US accounted for $28 \%$ of world GDP in 1970 and had a GDP per capita five times the global average. ${ }^{4}$

Investments by the rest of the world in higher education and research in the past half century or so has reduced US predominance in science and engineering. Advanced European countries recovering from World War II increased university enrollments and R\&D expenditures from the 1960s to the present. Japan and later the Asian Tiger economies did the same. Beginning in the 1990s developing countries substantially expanded their higher educational systems and scientific activity. Despite its low level of GDP per capita, China graduated huge numbers of scientists and engineers and poured

3 For enrollment data see Freeman, R. (2010) What Does Global Expansion of Higher Education Mean for the United States?” in Clotfelter Charles editor, American Universities in a Global Market University of Chicago Press http://www.nber.org/books/clot08-1 For other data see Science and Engineering Indicators 2014

4 http://www.ers.usda.gov/data-products/international-macroeconomic-data-set.aspx\#.UxR0FfldXw8. 
sufficient money into R\&D from the 2000s to 2013 to become a super-power in science and engineering, which will inevitably translate into innovation in high-tech and other sectors.

The rapidity with which China and other developing economies have moved toward the frontier in knowledge creation and in the application of advanced knowledge to the economy is arguably the great surprise of modern globalization. When Americans debated the NAFTA treaty two decades ago, analysts had no notion that in the near future low wage countries would increase their supplies of university educated workers and invest enough in R\&D to challenge the US in knowledge and technology intensive sectors. Proponents of free trade promised American workers that the solution to low wage competition from Mexico was university education. Opponents warned of the "giant sucking sound” of factory assembly jobs moving to Mexico to hire low wage workers. ${ }^{5}$

Post-NAFTA the proportion of young Americans in colleges and universities increased, driven by an influx of women. But continuing a trend that began as early as the 1970s, the proportion of young persons in tertiary education in other countries increased more rapidly than in the US. From 1970 to 2010 the US share of the world's university students fell from $29 \%$ to $11 \%$. In the 1970 s and 1980s the spread of mass higher education in Europe was the major factor in the decline of the US share of world college enrollments. ${ }^{6}$ By 2010 enough advanced countries had expanded their higher educational systems to drop the US from a top position to middle of the pack in the ranking of countries by the proportion of young persons in university. ${ }^{7}$

In the 1990s and 2000s the downward trend in the US share of world university students was largely driven by the expansion of higher education in China, India and other developing countries. In 1970 China had just 47,000 undergraduate students and essentially no graduate students (courtesy the

5 http://en.wikipedia.org/wiki/North_American_Free_Trade_Agreement. http://en.wikipedia.org/wiki/Giant_sucking_sound

6 See exhibit 1.

7 OECD, Education at a Glance, 2013 (Paris 2014), table A3.2a shows the US with a graduation rate of 39\% of the age group, which is exactly at the OECD average. The US was at the median rate for 25 countries in this table. http://www.oecd.org/edu/eag2013\%20(eng)--FINAL\%2020\%20June\%202013.pdf 
cultural revolution destruction of higher education). In 1980 China had 1.3 million undergraduates enrolled and 21,000 graduate students. In 1990, it had 2.1 million undergraduates and 93,000 graduate students. In 2000, 5.6 million undergraduates and 301,000 graduate students. ${ }^{8}$ By 2010, China had increased enrollments to 30 million students and graduated 6 million persons with bachelor's degrees. The other hugely populous country, India, expanded its higher educational system more slowly but still enrolled 21 million students in 2010. From 1970 to 2010 India more than doubled the number of Indian Institutes for Technology. ${ }^{9}$ According to the OECD (2013) in the 2000s, Mexico, the focus of the NAFTA debate, had the highest average annual rate of growth of first-time upper secondary graduation rates among OECD countries. Mexico increased its tertiary graduation by 6 percentage points between 2000 and 2011. Because the proportion of bachelor's degrees going to science and engineering in most countries exceeds the proportion in the US, increased enrollments and graduates overseas have an amplified effect in reducing the US share of B.S. scientists and engineers.

Exhibit 1 measures the globalization of scientific and engineering activity in terms of its impact on the US share of world research and S\&E activity, as given from data in the National Science Board's Science and Engineering Indicators and the OECD's Main Science and Technology Indicators Database. The data for the 2000s are based on comparable statistics that cover nearly identical samples of countries. The "world” data in earlier years are sparser and reported differently, giving cruder measure of the trends, with, for example, OECD measures of country R\&D differing modestly from the Science and Indicators measures for some countries, and so forth. ${ }^{10}$ To deal with this problem, I report modestly different statistics under some headings. The trend changes are sufficiently large to make it clear that

8 Li (2010) tables 8.1 and 8.2

9 http://en.wikipedia.org/wiki/Indian_Institutes_of_Technology

10 The cost of research varies greatly among countries depending on the wages of researchers and other expenses. A country in which researchers are paid $1 / 2$ as much as in another country could spend half as much for the same real activity. In the absence of R\&D specific exchange rates, the US National Science Foundation uses purchasing power parities to compare expenditures across countries in comparable units. 
global catch-up produced a huge drop in the relative position of the US, however measured.

First, the US share of R\&D spending and of researchers dropped sharply in the 2000s, as China expanded its scientific activities extraordinarily rapidly (lines 1 and 2). By 2011 China was the second biggest performer of $R \& D$, accounting for $18 \%$ of $R \& D$ among the countries covered while Japan accounted for $11 \%$. The largest EU performer Germany spent $8 \%$ of global R\&D but the EU in its entirety accounted for 28\%. ${ }^{11}$ With Asian countries beside China, Japan, and South Korea increasing R\&D substantially and with Brazil increasing its R\&D, the concentration of R\&D in the US and other advanced countries declined. The OECD series on the number of researchers follows a similar pattern, albeit subject to problems in consistency of statistics for some countries, notably China. By 2012 the OECD data show that China surpassed the US in the number of full-time equivalent research personnel.

Lines 3 and 4 turn to the US share of scientific and engineering publications and citations. The US share of global scientific papers held roughly steady from 1970 through 1990 then fell to $31 \%$ in 2000 and to $26 \%$ in $2011 .{ }^{12}$ The decline in the 1990s resulted largely from expanded activity in other advanced countries whereas the decline in the 2000s resulted largely from the huge increase in papers with addresses in China. The increased China share of papers exceeds the absolute value of the decline in the US share and was associated with smaller EU and Japan shares of world papers as well.

From the 1970s through 2000 the Indicators reports the US share of citations. Thereafter it reports the US share of articles in the upper $1 \%$ of the distribution of papers ordered by their citations. The US share of citations dropped commensurately with the drop in the share of papers from 1990 to 2000. In the 2000s the share of highly cited papers declines more in absolute and proportionate terms

11 Indicators, 2014, table 4-13.

12 The statistics measure the country share by fractional counts of country addresses/affiliations on papers. This may exaggerate the drop in US as producer of research papers by weighing the contribution of collaborations across country lines equally whereas US based researchers are particularly likely to be the principal investigator which in most fields is the last name on the paper. 
than the US share of all papers, as the rest of the world reduced the citation gap. China's increased share of top $1 \%$ cited papers falls short of the drop in the US share. But even though the US share of most highly cited papers fell, the US still maintained a remarkably high share given the decline in the US share of papers.

Turning to higher education, the exhibit shows that the US share of bachelor's science and engineering graduates and doctorate S\&E degrees fell from the 1970s through the 2000s. EU countries expanded doctorate science and engineering programs so rapidly that by 2010 the EU produced nearly twice as many natural sciences and engineering PhDs as the US - a differential that reflects in part the shorter time period for gaining a doctorate in those countries than in the US. In the 2000s, however, the big mover in the production of doctorate degrees was China, which increased its S\&E PhD graduates so rapidly that by 2007 the number of students obtaining natural science and engineering PhDs in China exceeded the number obtaining those degrees in the US. ${ }^{13}$ While the quality of China's graduate training falls short of that in the US, its jump from negligible producer of S\&E PhDs to top single country is remarkable. Recognizing its lag in the quality of doctorate education, moreover, China encourages top students to enroll in doctorate programs in the US and other advanced countries. It funds PhD students and researchers to spend a year overseas to improve their research skills. China is will almost certainly improve it's position in the knowledge-intensive and high-technology sectors of the economy on which the US relies for economic growth and comparative advantage in trade.

In 1990 virtually no major multinational undertook substantial R\&D in a developing country such as China. American-based firms concentrated their R\&D in the US with some investments in other advanced countries. In 2000 multinational firms had on the order of 120 R\&D centers in China. In 2013 multinational firms had over 1,300 R\&D centers in China. Sixty-one percent of R\&D

13 It fell short of the total science and engineering degrees due to much larger numbers of social science PhDs in the US. 
performing multinationals reported at least one research and development center in China. ${ }^{14}$ In 2013 , four of IBM's 12 major research facilities were in developing countries: China (established 1995), India (1998), Brazil (2010), and Kenya (2013). ${ }^{15}$ Companies locate R\&D around the world in part to be near the markets of consumers of their products or to be close to the production plants of their firm or its major suppliers. But the key factor in the spread of multinational research facilities worldwide is the new availability of qualified scientific and engineering workers in developing countries at lower wages than in advanced countries.

The development of the global solar energy industry provides a striking example of the changing advantages of the US and other advanced countries in a bulwark green technology. When the Obama Administration loaned substantial government funds to US solar manufacturers as part of its sustainable energy policies and spent $\$ 9$ billion in federal stimulus funds on green energy it did not appreciate the huge advances China had made in the sector, which reduced the prices of solar panels sufficiently to bankrupt several leading edge US firms. ${ }^{16}$ In 2012, for example. the Massachusetts firm A123 battery, which had received millions of dollars of US government R\&D support to develop innovative batteries, went bankrupt. In 2013 the Chinese automaker Wanxiang bought A123, only to sell the part of the firm that produced large batteries to store power from intermittent energy sources such as wind turbines to Japan's NEC corporation the following year. ${ }^{17}$ Further evidence of the spread of multinational investments, Massachusetts-based Applied Materials built what it calls "the world's largest and most advanced” solar R\&D facility in Xian “to take advantage of local research talent,

14 See KPMG Innovated in China: New frontier for global R\&D China 360 - Issue 11, 31 August 2013 15 http://www.research.ibm.com/labs/

16 For the progress of China's firms see Wang, Ucilia, Chinese Manufacturers Cement Their Hold On Global Solar Market Forbes /27/2012 and “180 Solar Panel Makers Will Disappear by 2015 Forbes http://www.forbes.com/sites/uciliawang/2012/10/16/report-180-solar-panel-makers-willdisappear-by-2015/

17 http://www.bostonglobe.com/business/2014/03/24/nec-buy-unit-waltham-batterymaker/H3hobthqsnyTR5DGVGER3N/story.html 


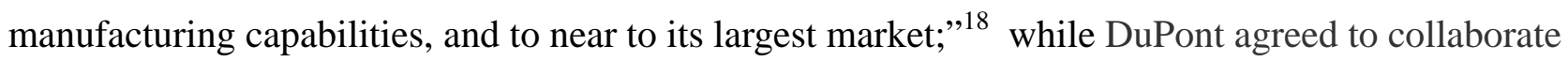
with China's GD Solar in materials research for the Chinese firms’ PV panels and systems. ${ }^{19}$

In sum, the US remains the lead country in R\&D worldwide but global catch-up has shrunk the US advantage and is likely to continue to do so into the foreseeable future. Whether or not China surpasses the US in R\&D spending in the next 10-15 years, as trend extrapolations suggest, the globalization of basic and applied science and of product development has created a new world of knowledge creation and application to the economic world.

\section{S\&E Globalization within the US}

Globalization affects science and engineering activity within countries as well as among countries. Within the US globalization takes several forms: international students who study in the US; postdoctoral students/workers from overseas in US laboratories; scientists and engineers who immigrate to the US; and collaborations between US researchers and overseas colleagues.

\section{International students}

International students are the fastest growing part of the global higher educational system.

Between 1975 and 2010 the number of international students increased nearly seven-fold, producing a growth rate about three times as large as that for tertiary education students worldwide. As the lead scientific country and highly desirable location for educated workers, the US is a major attractor of international students in science and engineering. In 2011 21\% of S\&E students enrolled outside their country of origin were enrolled in US institutions of higher education ${ }^{20}$. The top supplying countries for international students were China and India, with the Chinese more concentrated in the sciences and

18 Quan Barry, Oct 26, 2009 http://blog.appliedmaterials.com/worlds-most-advanced-solar-rd-center Bradisher, K “China Drawing High-Tech Research from US” NY Times, March 17, 2010 http://www.nytimes.com/2010/03/18/business/global/18research.html?_r=0

19 http://www.renewable-energy-technology.net/solar-energy-news/us-materials-producer-agrees-rd-deal-china-solar-firm 20 Ruiz, 2013 
the Indians more concentrated in engineering. Many international students obtain work visas to remain in the US for the early years of their scientific careers. Many become permanent immigrants.

Exhibit 2 shows the foreign-born proportions of US undergraduate and graduate enrollments, of bachelor's, Master's, and PhD S\&E degrees, and of post-doctoral students/workers. Although 33.2\% of foreign-born undergraduates were enrolled in S\&E in 2012, the foreign-born make up just 4.4\% of bachelors degrees is science and engineering. ${ }^{21}$ The percent in engineering exceeds that in the natural or social sciences but is still in single digits (6.3\%). International students are more highly represented at the graduate level, where they make up around one-third of S\&E enrollments, one quarter of master's degrees, one-third of PhDs, and over half of post-docs. The foreign born share of PhDs is lower in the biological sciences (27.4\%) than in physics (45.4\%) or engineering (56.2\%); and is lower in the social/behavioral sciences (19.7\%) than in the natural sciences (31.4\%). But the field with the highest proportion of doctorates going to foreign-born persons was economics (60.4\%) ${ }^{22}$ Among postdoctorates the foreign-born proportion is $60 \%$ in engineering compared to $30.3 \%$ in psychology ${ }^{23}$. Without the foreign-born, many US labs would close or shrink massively, at least in the short run.

The US treats applicants for student visas (and other non-immigrant visas) as potential immigrants who must declare to the consular officer that they do not intend to immigrate and have stronger reasons to return home than to move to the US. ${ }^{24}$ But this is pro forma declaration, as many international students stay in the US and work for years. Exhibit 3 gives two measures of the tendency for foreign-born PhDs to work in the US after graduation: the Survey of Doctorate Records (SDR) question on intention to work in the US upon graduation, and five year "stay rates" -- the proportion of

21 Science and Engineering Indicators 2014, table 2-19, p 65

22 Science and Engineering Indicators, 2014, Appendix table 2-31

23 NSF Graduate Students and Postdoctorates in Science and Engineering: Fall 2011 Detailed Statistical Tables | NSF 13331 | September 2013 http://www.nsf.gov/statistics/nsf13331/pdf/nsf13331.pdf table 34

24 See NAFSA, the association of International Educators, advice to persons seeking student visas. http://www.nafsa.org/Find_Resources/Supporting_International_Students_And_Scholars/Network_Resources/International_ Student_and_Scholar_Services/10_Points_to_Remember_When_Applying_for_a_Nonimmigrant_Visa/ 
doctorates with temporary visas that social security records show worked in the US five years after obtaining their doctorate degree. The SDR finds that about 3/4ths of graduates intend to work in the US as post-docs or at other jobs, which is consistent with the stay rates data that show that two thirds of PhDs in a given years' graduating cohort work in the US over the next five years. The stay rates are highest though declining for China and India and lower but rising in South Korea, Mexico, and Brazil. The consistency between the intentions of foreign-born doctorates to work in the US and ensuing work behavior implies that responses to the question on intentions is a good indicator of future behavior.

The attractiveness of the US to foreign students and their tendency to work in the country thereafter enlarges the US S\&E labor supply. To the extent that foreign-born graduates choose their country of work by comparing careers in their home country or other non-US locations to careers in the US while US graduates focus primarily on US opportunities, the greater the foreign-born share of doctorates, the more sensitive is the supply of US graduates to market conditions.

\section{Immigrant scientists and engineers}

Exhibit 4 moves from enrollments and degrees to employment in S\&E occupations for persons differentiated by level of degree. The foreign-born make up a substantial and increasing share of working scientists and engineers, with smaller shares for persons at the bachelor's level than for master's and doctorate graduates. In 2011 19\% of bachelor's scientists and engineers were foreign-born - a figure that far exceeds the foreign-born proportion of US S\&E bachelor's graduates. Since the number of foreign born workers consists of US trained and non-US trained foreign-born workers, the bachelor's proportion indicates sizable immigration of foreign-trained bachelor's degree scientists and engineers to the US. ${ }^{25}$ While the foreign-born shares of Master's and PhD S\&E workers are close to the foreign-born shares of S\&E graduates with those degrees, substantial numbers of US-educated foreign

25 This also reflects the greater likelihood that foreign-born persons with US S\&E bachelor's degrees work in S\&E occupations than their native-born peers. 
born masters' and doctorate graduates leave the US, so that the final number of foreign-born scientists and engineers with PhDs and Masters degrees also reflects immigration of persons trained overseas. Asked why they came to the US, foreign-trained immigrants give job/economic opportunities (29\%) as the most important factor, followed by family situations (23\%), scientific or professional infrastructure (11\%), and educational opportunities (10\%) ${ }^{26}$

Since far more foreign-born university graduates obtain their highest degrees outside the US than in the US, one might expect that the number of foreign-trained foreign-born scientists and engineers working in the US would far exceed the number of US trained foreign-born scientists and engineers. The opposite is true. Exhibit 5 shows that in 2005 the majority of foreign-born scientists and engineers in the country were US-trained. The NSF's SESTAT data file tells a similar story. Over half of foreign-born scientists and engineers working in the United States obtained their bachelor's degree in the US. Two thirds of those with a doctorate or master's degree completed their highest degree in the US while, by contrast, only one-quarter of foreign-born scientists and engineers with an advanced degree received both their first and highest degree abroad and thus came to the US on immigrant visas rather than student visas. ${ }^{27}$

Why are international students such a large source of immigrant scientists and engineers?

One likely reason is that students who come to the US self-select from persons especially attracted to the US with a high penchant to immigrate given the opportunity. What makes the US especially attractive to them? The single most popular reason foreign-born graduates from US institutions is, not surprisingly, educational opportunity (27\%). ${ }^{28}$ Another factor likely to induce international students to immigrate to the US is accrual of US-specific knowledge, from career to social

26 Science and Engineering Indicators 2014, p 2-54 for persons who received both degrees abroad 27 Science and Engineering Indicators 2014, pm3-53 and 3-54

28 Science and Engineering Indicators 2014, p 3-54 
connections. $^{29}$

In sum, immigrant scientists and engineers to the US come largely from international students, which makes the attractiveness of US higher education and policies toward student visas an intrinsic part of policies toward the immigration of scientists and engineers.

\section{international collaborations in research papers}

Scientific research has moved from lone investigators to collaborative research, producing an upward trend in authors per paper (Jones, Wuchty and Uzzi, 2008; Wuchty, Jones and Uzzi, 2007; Adams, Black, Clemmons, and Stephan, 2005). Papers with larger numbers of authors are especially likely to be published in journals with high impact factors and garner relatively many citations (Lawani, 1986, Katz and Hicks, 1997; deB. Beaver, 2004, Wuchty et al., 2007; Freeman and Huang, 2014a). These outcomes offer a potential productivity justification for increased collaborations. In the past two decades the trend in co-authorship has extended across country lines, with a larger proportion of papers coauthored by scientists from different countries (Indicators, 2014; Adams, 2013).

Exhibit 6 examines the pattern and change in internationally co-authored papers and the position of the US and its main collaborating partners in these collaborations. The columns "share of S\&E articles internationally co-authored” records the ratio of articles with two or more international addresses relative to all articles for the specified group. The shares increase for the world, the US and and other countries, though only modestly for China and South Korea, whose numbers of articles increased largely through within-country collaborations. Internationally co-authored articles are a smaller share of articles for the US and Japan than for European countries and for Canada and

29 Data from the European Union's Erasmus Program - a scholarship program that funds short study periods for EU students in other EU countries - findsto assay the effect of overseas educational experience on working abroad. Parey and Waldinger (2008) estimate that being in the Erasmus program increases the likelihood of working overseas by 20 percentage points. Oosterbeek and Webbink, 2009; Grip, Fouarge and Sauermann, 2008; Dreher and Poutvaara, 2008 find similar magnitudes for being an international student on working in a foreign country for EU students. Since Erasmus funds short periods of study, its estimated impact is likely to be a lower bound on the effect of international study in the US on migration decisions of international students. 
Australia, presumably because the US and Japan have much larger researcher populations, which creates a larger pool for intra-country collaborations. The table shows somewhat surprisingly a higher share of internationally co-authored papers for individual countries than for the world, in most cases by large amounts. The reason is that the Science Indicator tabulations count an international paper with coauthors from two countries as a single paper at the world level but as two international papers at the country level, with a count of one for each country.

The columns "US share of international collaborations" record the ratio of papers in which at least one author has a US address and at least one has an address in another country divided by the total number of international collaborations for the relevant entity. The US is a huge contributor to international collaborations worldwide, with $43.8 \%$ of world collaborations in 1997 and $43 \%$ of world collaborations in 2012. That the US maintained its share of world collaborations in a period when the US share of papers fell markedly is indicative of the US position as a hub of world science. In 2012 the countries with particularly large US shares of international collaborations were South Korea, Canada and China. The surprise relative to earlier years is China, whose collaborative research with the US increased greatly in the 2000s so that the US share of China collaborations exceeds the US share of all international collaborations.

The columns "Country shares of US international collaborations" give the ratio of the number of papers in which an address for the given country appears along with a US address on the paper divided by all US international collaborations. The "country shares" are lower than the "US shares" because the number of papers by US-based scientists far exceed the number of papers in the other countries. The most striking change in these columns is for China, which increased its share of US international collaborations fivefold to become the leading collaborator for US scientific papers.

The huge increase in China-US collaborations suggests that the two countries are developing a "special relationship" in science and engineering. Because many international students and post- 
doctoral students in the US are Chinese, the tie between US and Chinese researchers extends to collaborations within the US. Freeman and Huang (2014a) find that in the late 2000s 14\% of the names on research papers with only US addresses were Chinese names, the vast majority whose first names or initial indicate that they were born outside the US (Xu Wang rather than Andrew Wang). Within China, moreover, a substantial number of highly productive researchers have US-research experience, as indicated by their having written papers with only US-addresses. The decision of the Chinese government to fund Chinese students and faculty to spend up to one year studying and working in the US and other advanced countries has fueled the growing link between the US and China.

What is the impact of international collaborations on the quality of scientific papers and US science in particular?

It is well-established that papers with international collaborators are published in higher impact journals and obtain more citations than papers with solely domestic collaborators (Katz and Hicks (1997), Rigby (2009), Adams (2013). One possible interpretation is that international collaborations add a special synergy to research. But international collaborations average more authors than single country collaborations. Given that numbers of authors is associated with greater impact factors and citations, the international collaboration edge could simply reflect numbers of authors on those collaborations. Regressions of impact factors and citations on whether papers in Nanoscience and Nanotechnology, Biotechnology and Applied Microbiology, and Particle and Field Physics have international addresses show that introduction of numbers of authors changes the sign on the variable for international collaborations from positive to negative (Freeman, Ganguli, and Muricano-Goroff, 2014). In these fields international collaborations look better because they are bigger than domestic collaborations.

At the same time, international collaborations between researchers from the US, a top country 
in impact factors and citations, and researchers from countries lower in those outcomes are likely by the arithmetic of averages likely to produce lower impact factors and citations for international collaboration than for domestic collaborations for the US and higher impact factors in the country with lower average outcomes than for its domestic collaborations. Who collaborates with who should matter in the impact factors and citations associated with international collaborations. Examining impact factors and citations for US-China collaborations Freeman and Huang (2014b) find such patterns with some twists that illuminate the special research relation between the two countries. On average, US-China collaborations have impact factors and citations that lie between the US's high impact and citation numbers and the relatively low but increasing impact factors and citations for China. The twists are: (1) that researchers in China with US research experience (defined as having an earlier paper solely with a US address) have higher impact factors and citations on their Chinaaddressed papers than are found for other China-addressed papers, which suggests that the Chinese researchers increase their research skills working in the US; and (2) that US addressed papers with a Chinese first author gain higher impact factors and citations than other US addressed papers, suggesting that US research gains from attracting some of China's best and brightest young post-docs and graduate students; and (3) that Chinese researchers with US experience have higher impact factors and citations when they work in the US than when they work in China. A natural interpretation of the better outcomes for Chinese researchers when they are in the US is the country's exceptional climate for scientific work. ${ }^{30}$

\section{Conclusion: “A policy, a policy - My kingdom for a policy”}

Today's world of global science and engineering diverges greatly from the world war II/cold

30 This is consistent with Khan and McGarvie (2012)'s finding that the Foreign Fulbright Program requirement that Fulbright recipients return to their home countries before applying for a work visa in the United States reduced their scientific productivity compared to what it would have been had they remained in the US. 
war period when the US developed its science and technology policy ${ }^{31}$. The spread of knowledge discovery and of knowledge throughout the world has reduced the US edge in high tech and knowledge intensive activities. Developing countries have the human resources to produce scientific and technical breakthroughs and the manufacturing capability to produce innovative goods and services that economists once viewed as in the province of advanced countries. The US's S\&E workforce increasingly consists of immigrant scientists and engineers, many of whom come to the country as international students. Students, immigrant researchers, and collaborations with Chinese researchers have become critical in US scientific activity.

The US has considerable assets in the global knowledge economy: the world's preeminent higher education system, ${ }^{32}$ which draws the best and brightest students from around the world; a large exemplary research enterprise that is the hub of global research and international collaborations; a successful innovation system protected by intellectual property rights and a business culture that encourages start-ups to translate research findings into goods and service. The danger to the US is that other countries, particularly those with lower wages and labor costs, will produce an increasing proportion of the science and engineering-based innovations and reduce the US's comparative advantage in science-based discovery and its application to the economy, adding a trade $\mathrm{x}$ technology twist to the economic problems facing many US workers. What types of policies might help the country benefit from the new globalization of knowledge and avoid the dangers?

\section{More economics in assessing the country's research portfolio}

31 Roosevelt appointed Vannevar Bush the first science adviser to the President in 1939. The US established office of science and technology policy in the White House in 1976. Congress established the office of Office of Technology Assessment (OTA) from 1972 to 1995 http://en.wikipedia.org/wiki/Office_of_Science_and_Technology_Policy. http://en.wikipedia.org/wiki/Office_of_Technology_Assessment

32 The US has a disproportionate share of top universities in every global ranking. See, for example, the ratings by world universities by Center for World-Class Universities at Shanghai Jiao Tong University, which place 8 of top 10 in US http://www.shanghairanking.com/ARWU2013.html. The Times rankings have 7 of top 10 in US http://www.timeshighereducation.co.uk/world-university-rankings/2013-14/world-ranking, but its reputation rankings have 8 of 10 top in US. http://www.timeshighereducation.co.uk/world-university-rankings/2014/reputation-ranking 
In a world where economic growth and comparative advantage depend critically on science and technology, it seems sensible for S\&T policy to focus more on the potential impacts of science and engineering on the future state of the economy than in earlier times when the primary goal of S\&T policy was to give expert input to decision-makers on complex scientific and technical issues. Policies toward $R \& D$ are an important tool for encouraging economic activity in some areas rather than in other - a new industrial policy, as it were. If the government puts more money into the basic research that underpins a given industry, supports its R\&D with R\&D tax credits, purchases its advanced products, or enacts regulations favoring those products, that industry is likely to prosper compared to competitor industries. The country's research portfolio and policies will thus influence the future composition of output and employment.

Since the 1990s NIH doubling if not earlier the US research portfolio has been more heavily invested in biological and medical sciences than the research portfolios of other major countries. In 2011 51.6\% of US research moneys went to the biomedical fields compared $43.3 \%$ of EU research moneys, $42 \%$ of Japan's research moneys and $26 \%$ of China's spending. ${ }^{33}$ The concentration on biomedical sciences reflects the Clinton Administration's late 1990s policy of doubling the NIH budget and Senator Arlen Specter's support of the doubling in budget deliberations; and American Recovery and Reinvestment Act stimulus funding for NIH due to Senator Specter's favoring biomedical sciences. These expenditures affected the educational and career decisions of science students, the direction of scientific research, and the types of immigrant scientists and post-doctoral students that have come to the country. Science and technology policy should bring more economics to bear in assessing the research portfolio and helping guide decisions by policy-makers.

\section{Resources for moving R\&D outcomes to production in the US}

33 Science and Engineering Indicators, 2014, table 5-21 
The biggest problem that the globalization of knowledge and knowledge-creation presents to the US is that innovative goods and services developed by US research expenditures will increasingly be produced in lower wage countries, adversely affecting many US workers. What policies might enhance the ability of the US to hold its own in this terrain?

The high responsiveness evinced by students to fellowships offers a possible way to affect education and career decisions in ways that would strengthen the link from scientific progress to production. When the NSF nearly doubled the value of Graduate Student Fellowships in the late 1990s and early 2000s, the number and quality of applicants rose sharply, and seemed to raise graduate students enrollments broadly (Freeman, Chang, and Chiang, 2009). The Obama Administration's expansion of the number of NSF Fellowships in the late 2000s was associated with increased graduate enrollments and PhDs for US-born and permanent residents roughly consistent with predictions of its impact (Freeman, 2006). Given this evidence, and the potential benefit from increased efforts to translate scientific findings into production, it would be worthwhile to consider a new set of fellowships for master's or doctorate graduates specializing in the transformation of knowledge into US production. Such a program would produce scientists and engineering specialists in what the NIH calls “translational sciences". ${ }^{34}$

To focus business thinking on increased production of R\&D based goods and services in the US the government could consider requiring federal contractors or firms that benefit from R\&D tax credits or receive direct government support for R\&D to develop impact statements about the likely effects of technological advances and innovations and to make affirmative action plans for ways to produce those products in the US rather than overseas. National and many states require firms to make environmental impact statements if their actions are likely to significantly affect the quality of the human

34 The sluggish translation of biomedical science findings into drug development or other medical practices sufficiently upset NIH that in 2011 the agency established the National Center for Advancing Translational Sciences to transform the translational science process so that new treatments and cures for disease can be delivered to patients faster. 
environment. ${ }^{35}$ Governments also require government contractors and subcontractors to take affirmative action to prevent discrimination against employees or applicants for employment on the basis of "color, religion, sex, or national origin," where affirmative action may include outreach campaigns, targeted recruitment, and employee support programs. These programs have affected the way business thinks about its activities in both areas. If impact statements on the location of production from taxpayer supported research had the same effect on corporate thinking as environmental impact and affirmative action statements, they could influence the location of production of innovative products and processes.

Combining fellowships to develop expertise in translation of research findings into product development and corporate impact statements with consideration of US- production would gave these initiatives better chances for success than if they were introduced by themselves.

\section{international students and immigration}

In a world where knowledge creation and the application of science and engineering based knowledge is in the comparative advantage of the US, it makes little economic sense to place hurdles on international students from working in the US as permanent citizens or residents. Such hurdles lower the attractiveness of the US as a destination for international students relative to countries such as Australia and Canada and others who seek to attract such students by offering them legs up in immigration. Given general agreement in the Congress and elsewhere that modernizing immigration policy to ease the path of international students to work in the US is in the country's interest, I limit my comments to the nature of the debate. Policy discourse in this area often presents the situation as a win-win. This exaggerates the benefits of admitting more STEM or other highly educated immigrants to the US and downplays the costs. The basic economics of immigration indicates that much of the benefits accrue to the immigrant (which is why they want to come) and that greater supply of 
competitors adversely affects US workers in the same field as the immigrants (Borjas, 2006). There is no need for exaggeration, however, to make the case that in a world in which science and technology are critical in economic growth and comparative advantage that the US would gain in those activities by keeping as many of the best and brightest from overseas who come to the country for education to continue their work in the US if they so desire. As long as the US maintains world leadership in university education and research, with researchers doing better work in the US and US-educated researchers doing better work elsewhere in the world, it is likely that the aligning US immigration policies with its international policies is in the world's interest as well.

Science and technology policy can make the US and world better today in ways that it never could have done before. 
Exhibit 1: US Percentage of World Research and Scientific Activity, 1970-2011 and change in share compared to change in share of China, 2000s-2011

\begin{tabular}{|c|c|c|c|c|c|c|}
\hline & \multicolumn{4}{|c|}{ US level/World level in \% Units } & \multicolumn{2}{|c|}{$\begin{array}{l}\text { Change in \% } \\
2000 \text { to } 2011\end{array}$} \\
\hline & 1980 & 1990 & 2000 & 2011 & US & China \\
\hline $\begin{array}{l}\text { 1, R\&D spending } \\
\text { a) All countries, Indicators } \\
\text { b) Major R\&D countries* } \\
\text { c) All countries, OECD }\end{array}$ & $\begin{array}{l}45 \\
44\end{array}$ & $\begin{array}{l}43 \\
36\end{array}$ & $\begin{array}{l}45 \\
40\end{array}$ & $\begin{array}{l}32 \\
38 \\
33\end{array}$ & $\begin{array}{l}-7 \\
-7 \\
\end{array}$ & $\begin{array}{l}+13 \\
+14\end{array}$ \\
\hline 2. Researchers & & & 22 & 20 & -2 & 5 \\
\hline 3. S\&E papers & 37 & 37 & 31 & 26 & -5 & +8 \\
\hline $4 \mathrm{~S} \& \mathrm{E}$ citations & 53 & 50 & 43 & & & \\
\hline articles in upper $1 \%$ citation & & & 57 & 46 & -11 & +6 \\
\hline $\begin{array}{l}\text { 5. S\&E bachelor's } \\
\text { a) Relative to select countries } \\
\text { b) Relative to world }\end{array}$ & 23 & & 14 & 10 & -4 & +14 \\
\hline $\begin{array}{l}\text { 6. S\&E PhDs } \\
\text { a) Relative to select countries } \\
\text { b) Relative to world }\end{array}$ & 52 & 41 & $\begin{array}{l}34 \\
22\end{array}$ & 16 & -6 & +5 \\
\hline
\end{tabular}

Source: National Science Board, Science and Engineering Indicators, 1982, 1987, 2002, 2014

* "World" limited to EU, US, Japan, South Korea, and China

1 - a for all countries, Science and Engineering Indicators, 2014, table 4-4;

b for major RD countries, Appendix table 4-13, with 1981 for 1980, EU estimated on basis of France, Germany and UK relative to total EU for 1995;

c Downloaded from http://stats.oecd.org/Index.aspx?DataSetCode=MSTI_PUB, with 1981 for 1980 and missing years for a few countries extrapolated/interpolated from data for nearest years

2 Total researchers, FTE Downloaded from

http://stats.oecd.org/Index.aspx?DataSetCode=MSTI_PUB, Data for earlier years too spotty, with no figures for Russian Federation and other major non-OECD countries

3 Science and Engineering Indicators, 2014, appendix table 5-26. Earlier years from Science and Engineering Indicators, 1982, 1987, 2002

4 Science and Engineering Indicators, 2014, appendix table 5-57, Earlier years from Science and Engineering Indicators, 1982, 1987, 2002

5 Science and Engineering Indicators, 2014. Earlier years from Science and Engineering Indicators, 1982, 1987, 2002

6 Science and Engineering Indicators, 2014. Earlier years from Science and Engineering Indicators, 1982, 1987, 2002 
Exhibit 2: Percentage Foreign-Born or with temporary visa of US S\&E Graduate Enrollments and Degrees, 1970-2011/12

\begin{tabular}{|l|l|l|l|l|l|}
\hline & 1970 & 1980 & 1990 & 2000 & $2011 / 12$ \\
\hline $\begin{array}{l}\text { 1. Graduate students, full-time, } \\
\text { in science and engineering* }\end{array}$ & & $22.5 \%$ & $33.9 \%$ & $36.3 \%$ & $36.3 \%$ \\
\hline $\begin{array}{l}\text { 2. Bachelor's Degrees, } \\
\text { engineering }\end{array}$ & & $3.8 \%$ & $3.6 \%$ & 3.8 & 4.4 \\
\hline 3. Master's Degrees & 18.4 & 26.4 & 31.8 & 30.4 & 34.2 \\
\hline 4. Doctorate Degrees, & & 38.6 & 51.1 & 58.2 & 62.9 \\
\hline 5. All Post-doctoral Workers & 17.5 & 18.3 & 39.1 & 43.0 & 49.0 \\
\hline $\begin{array}{l}\text { 6. Post-doctoral in university } \\
\text { jobs for US doctorates only }\end{array}$ & & 22.6 & 25.8 & 26.0 \\
\hline
\end{tabular}

* This excludes medical students

Source:

1. NSF Graduate Students and Postdoctorates in Science and Engineering: Fall 2011 Detailed Statistical Tables | NSF 13-331 | September 2013

http://www.nsf.gov/statistics/nsf13331/pdf/nsf13331.pdf tables 5 and 8

2.Science and Engineering Indicators 2014, table 2-23; Science and Engineering Indicators 2002, appendix table 2-17, with 1981 for 1980 and 1991 for 1990

3.Science and Engineering Indicators 2014, table 2-30; Science and Engineering Indicators 2002, appendix table 2-23, with 1981 for 1980

4.Science and Engineering Indicators 2014, table 2-31;

5 Graduate Students and Postdoctorates in Science and Engineering: Fall 2011 Detailed Statistical Tables | NSF 13-331 | September 2013 table 27 and 3.

6 Science and Engineering Indicators 2014, table 5-17 
Exhibit 3-- Five Year Stay Rates and Plans to Stay in US, by Graduating Class

\begin{tabular}{|l|l|l|l|l|}
\hline & $1996-1998$ & $2000-2002$ & $2004-2006$ & $2008-{ }^{`} 11$ \\
\hline Stay Rates & 61 & 65 & 64 & -- \\
\hline Plans to Stay & 68 & 73 & 76 & 75 \\
\hline & & & & \\
\hline Stay rates by country & & & & \\
\hline China & 96 & 95 & 87 & -- \\
\hline India & 90 & 86 & 81 & \\
\hline Europe & 58 & 67 & 61 & \\
\hline South Korea & 29 & 43 & 42 & \\
\hline Japan & 32 & 37 & 39 & \\
\hline Mexico & 31 & 33 & 37 & \\
\hline Brazil & 26 & 32 & 35 & \\
\hline
\end{tabular}

Source: Stay rates, Finn 2012, averaged for consistency with plans to stay data in Indicators, 2014, table 5-32. Indicators, 2002 figure 2-21. 
Exhibit 4 Percent Foreign-Born in S\&E Occupations, by education level, 1990-2011

\begin{tabular}{|l|l|l|l|}
\hline Foreign-Born & 1990 & 2000 & 2011 \\
\hline All College Graduates in S\&E & & 22.4 & 26.2 \\
\hline Bachelor's & $11.00 \%$ & 16.5 & 19.0 \\
\hline Master's & $19.00 \%$ & 29.0 & 34.3 \\
\hline PhDs & $24.00 \%$ & 37.6 & 43.2 \\
\hline
\end{tabular}

Source: Science and Engineering Indicators 2014, table 3-27. 
Exhibit 5: Proportions of US Science and Engineering Workers that are Foreign-Born and the Proportion of the Foreign-Born that Have Highest Degree in the United States, 2005

\begin{tabular}{|l|c|c|}
\hline & Foreign-Born Share of Workers & $\begin{array}{c}\text { Share of Foreign-Born with } \\
\text { Highest Degree in US }\end{array}$ \\
\hline Bachelor's & $15.2 \%$ & $54.3 \%$ \\
\hline Masters & $27.2 \%$ & $68.5 \%$ \\
\hline Doctorates & $34.6 \%$ & $64.00 \%$ \\
\hline
\end{tabular}

Source: NSB, 2008. Table 3-8. 
Exhibit 6 : Shares of International Co-authorship US and Major Collaborators with US

\begin{tabular}{|l|l|l|l|l|l|l|}
\hline & \multicolumn{2}{|l|}{$\begin{array}{l}\text { Share of S\&E articles } \\
\text { internationally co-authored }\end{array}$} & \multicolumn{2}{l|}{$\begin{array}{l}\text { US share of Country's Intl } \\
\text { Collaborations }\end{array}$} & \multicolumn{3}{l|}{$\begin{array}{l}\text { Country's Share of US Int'l } \\
\text { Collaborations }\end{array}$} \\
\hline & 1997 & 2012 & 1997 & 2012 & 1997 & 2012 \\
\hline World & $15.7 \%$ & $24.9 \%$ & 43.8 & 43 & --- & -- \\
\hline US & 19.3 & 34.7 & -- & -- & --- & -- \\
\hline China & 25.7 & 26.7 & 35.1 & 47.5 & 3.2 & 16.2 \\
\hline UK & 31.0 & 55.1 & 30.0 & 35.2 & 12.4 & 14.3 \\
\hline Germany & 35.5 & 55.5 & 29.9 & 31.0 & 13.3 & 13.3 \\
\hline Canada & 33.5 & 50.2 & 53.0 & 48.9 & 12.1 & 11.4 \\
\hline France & 37.3 & 58.2 & 28.4 & 28.5 & 8.9 & 8.8 \\
\hline Italy & 36.1 & 51.1 & 32.2 & 34.0 & 6.8 & 7.4 \\
\hline Japan & 16.4 & 30.0 & 44.4 & 37.1 & 9.9 & 6.8 \\
\hline Australia & 29.4 & 52.4 & 36.1 & 32.9 & 4.3 & 6.0 \\
\hline South Korea & 27.6 & 30.8 & 51.5 & 53.9 & 2.8 & 6.0 \\
\hline
\end{tabular}

Source: Tabulated from Indicators 2014, Appendix table 5-41 and 5-56 


\section{References}

Adams, J. (2013). “Collaborations: The Fourth Age of Research.” Nature, 497(7451), 557-560.

Adams, J. D., Black, G. C., Clemmons, J. R., \& Stephan, P. E. (2005). “Scientific Teams And Institutional Collaborations: Evidence From US Universities, 1981-1999.” Research Policy, 34(3), 259-285.

Barrantes Bárbara S. Lancho, Vicente P. Guerrero Bote, Zaida Chinchilla Rodríguez, Félix de Moya Anegón (2012). "Citation Flows in the Zones of Influence of Scientific Collaborations” Journal of the American Society for Information Science and Technology, Volume 63, Issue 3, pages 481-489, March 2012.

Borjas, G. 2006. Immigration in high-skill labor markets: The impact of foreign students on the earnings of doctorates. NBER Working Paper 12085, National Bureau of Economic Research (NBER), Washington, DC.

De Grip, A., D. Fouarge, and J. Sauermann. 2008. What affects international migration of European science and engineering graduates? Research Memoranda 006, Research Centre for Education and the Labour Market (ROA), Maastricht.

Dreher, A., and P. Poutvaara. 2005. Student flows and migration: An empirical analysis. IZA Discussion Paper 1612, Institute for the Study of Labor (IZA), Bonn.

Erasmus Programme. http://en.wikipedia.org/wiki/ERASMUS_programme

Finn, M. 2012. Stay rates of foreign doctorate recipients from US universities 2009 Science Education Programs Oak Ridge Institute for Science and Education

Freeman, Richard 2006 "Investing in the Best and Brightest: Increased Fellowship Support for American Scientists and Engineers” downloadable from http://www.hamiltonproject.org/files/downloads_and_links/Investing_in_the_Best_and_Brightest_Increased_Fellowship_Support_for_American_Scientists_and_Engineers.pdf

Freeman, Richard B. 2010 “Globalization of Scientific And Engineering Talent: International Mobility of Students, Workers, and Ideas and The World Economy.” Economics Of Innovation And New Technology, Volume 19, issue 5, 201 pp. 393-406.

Freeman, Richard, Tanwin Chang, and Hanley Chiang 2009 "Supporting The Best and Brightest in Science and Engineering: NSF Graduate Research Fellowships” in Richard B. Freeman and Daniel Goroff "Science and Engineering Careers in the United States, University of Chicago Press

Freeman, Richard B. and Wei Huang, (2014a). "Collaborating With People Like Me: Ethnic Coauthorship within the US.” NBER WP 19905

Freeman Richard B and Wei Huang, Research Collaborations between Chinese and US Scientists and Engineers: A New Special Relationship?American Economic Association Jan 5, 2014 
Freeman, Richard B. Ina Ganguli Raviv Murciano-Goroff (2014) Why and Wherefore of Increased Scientific Collaboration NBER WP 19819

Gomory, R., and W. Baumol. 2000. Global trade and conflicting national interests. Cambridge, MA:MIT Press.

Guerrero Bote, Vicente P. Carlos Olmeda-Gómez Félix de Moya-Anegón (2013). “Quantifying the Benefits of International Scientific Collaboration,” Journal of the American Society for Information Science and Technology, Volume 64, Issue 2, pages 392-404, February 2013.

Hsu, J.W., \& Huang, D.W. (2011). “Correlation Between Impact and Collaboration.” Scientometrics, 86(2), 317-324.

Jones, B. F., Wuchty, S., \& Uzzi, B. (2008). “Multi-University Research Teams: Shifting Impact, Geography, And Stratification In Science.” Science, 322(5905), 1259-1262.

Khan Shulamit and Megan MacGarvie "The Effects of the Foreign Fulbright Program on Knowledge Creation in Science and Engineering” in Josh Lerner \& Scott Stern, 2012. "The Rate and Direction of Inventive Activity Revisited," NBER Books, National Bureau of Economic Research, Inc, number lern11-1, November.

Katz, J.S. And D.Hicks (1997). "How Much Is a Collaboration Worth? A Calibrated Bibliometric Model,” Scientometrics, 40:3, 541-554.

Krugman, P. 1979. A model of innovation, technology transfer, and the world distribution of income. Journal of Political Economy 87: 253-66.

Lawani, S. M. (1986). “Some Bibliometric Correlates Of Quality In Scientific Research,” Scientometrics, 9:1-1 13-25. 21

Lee K, Brownstein JS, Mills RG, Kohane IS (2010). "Does Collocation Inform the Impact of Collaboration?” PLoS ONE 5(12): e14279. doi:10.1371/journal.pone.0014279

Li, Haizheng “Higher Education in China: Complement or Competition to US Universities?” In Clotfelter, Charles American Universities in a Global Market University of Chicago Press 2010

National Science Board. 1998. Science and engineering indicators 1998. National Science Foundation (NSF 98-1). Arlington, VA: National Science Foundation.

National Science Board. 2006. Science and engineering indicators 2006. 2 Vols (Vol. 1, NSF 0601; Vol. 2, NSF 06-01A). Arlington, VA: National Science Foundation.

National Science Board. 2008. Science and engineering indicators 2008. 2 Vols (Vol. 1, NSF 0801; Vol. 2, NSF 08-01A). Arlington, VA: National Science Foundation

National Science Board (2014). Science and Engineering Indicators, 2014. 
OECD 2013 Education at a Glance 2013, Mexico country notes http://www.oecd.org/edu/Mexico_EAG2013\%20Country\%20Note.pdf

Oosterbeek, H., and D. Webbink. 2009. Does studying abroad induce a brain drain? Economica, December: 1-20.

Parey, M., and F. Waldinger. 2008. Studying abroad and the effect of international labor market mobility: Evidence from the introduction of ERASMUS. IZA Discussion Paper 3430, Institute for the Study of Labor (IZA), Bonn.

Ruffin, R.J., and R.W. Jones. 2007. International technology transfer: Who gains and who loses? Review of International Economic 15: 209-22.

Ruiz, Neil 2013 “Immigration facts on Foreign Students” http://www.brookings.edu/research/interactives/2013/facts-on-foreign-students.

Wuchty, S., Jones, B. F., \& Uzzi, B. (2007). “The Increasing Dominance Of Teams In Production Of Knowledge.” Science, 316(5827), 1036-1039. 